\title{
A palavra na bigorna do discurso
}

\author{
Márcio Roberto Soares Dias ${ }^{1}$
}

Em "Famigerado", do livro Primeiras estórias, a potencialidade da violência das relações humanas está em pauta. O fulcro do conto é o estado de tensão, precipitado através de um evento inusitado, que atravessa o diálogo de dois homens que se vêem pela primeira vez: o afamado facínora Damázio Siqueira viaja léguas para visitar o narrador, muito provavelmente um médico, na esperança que este lhe revele o significado que se esconde atrás de uma palavra. $\mathrm{Na}$ verdade, o estado crescente de apreensão, que parece encaminhar-se para um clímax, está manifesto somente, como mais tarde será revelado, na alma ou nas palavras do personagem que relata os acontecimentos. Tal conflito (mesmo sendo produto apenas da imaginação de um espírito inquietado por se ver uma situação inusitada), em virtude de desenrolar-se na dimensão do verbal, faz sobressair, no entanto, uma questão bem importante. Trata-se da disputa tácita e constante dos homens que põe em relevo as relações de poder na esfera simbólica e cultural pela autoridade de nomear e de impor atribuições a pessoas e objetos. A esse respeito, Maurice Blanchot já advertiu que

\begin{abstract}
A linguagem, no mundo, é por excelência poder. Quem fala é o poderoso e o violento. Nomear é essa violência que afasta o que é nomeado para o ter sob a forma cômoda de um nome. Só o nomear faz do homem essa estranheza inquietante e perturbante que deve afligir os outros seres vivos e até aqueles deuses solitários de que se diz serem mudos. Nomear apenas foi dado a um ser capaz de não ser, capaz de fazer desse nada um poder, desse poder a violência decisiva que abre a natureza, a domina e a força. É assim que a linguagem nos lança na dialética do senhor e do escravo, que nos obceca. O senhor adquiriu direito de palavra porque foi até o fim do risco de morte: só o senhor fala porque é ordem. O escravo limita-se a ouvir. Falar, eis o que é importante; aquele que só pode ouvir depende da palavra e só vem em segundo lugar. Mas o ouvir, esse lado deserdado, subordinado e secundário, revela-se afinal o lugar do poder e o princípio da verdadeira dominação. (BLANCHOT, 1984, p. 40)
\end{abstract}

Em "Famigerado", a potencialidade da violência das relações humanas desloca-se, por intermédio do discurso do narrador, da esfera do tangível para a esfera simbólica. No início do conto, é o personagem Damázio Siqueira, o homem “com dezenas de carregadas mortes” (ROSA,

\footnotetext{
${ }^{1}$ Professor Titular da Universidade Estadual do Sudoeste da Bahia. E-mail: marcio_uesb@yahoo.com.br
} 
1988, p. 13)2, que provoca a inquietação inesperada e súbita do sobressalto, perturbando a ordem e o equilíbrio no mundo do narrador:

Foi de incerta feita - o evento. Quem pode esperar coisa tão sem pés nem cabeça? Eu estava em casa, o arraial sendo de todo tranquilo. Parou-me à porta o tropel. Cheguei à janela. Um grupo de cavaleiros. Isto é, vendo melhor: um cavaleiro rente, frente à minha porta, equiparado, exato; e, embolados, de banda, três homens a cavalo. Tudo, num relance, insolitíssimo. Tomei-me nos nervos. (p. 13)

A virtual violência de Damásio Siqueira será apresentada, por assim dizer, de forma tangível através da sua própria fisionomia: "Carregara a celha. Causava outra inquietude, sua farrusca, a catadura de canibal.” (p.14), das suas armas: "Dava para se sentir o peso da de fogo, no cinturão, que usado baixo, para ela estar-se já ao nível justo, ademão (...) Sendo a sela, de notar-se, uma jereba papuda urucuiana” (p.14), dos seus gestos :“o cavaleiro solerte tinha o ar de regê-los (os seus acompanhantes): a meio-gesto, desprezivo, intimara-os de pegarem o lugar onde agora se encostavam" (p.13). São esses os indícios que desestabilizam a serenidade do narrador. Trata-se dos primeiros momentos do conto e que dão ciência, assim, do poder do jagunço percebido através do semblante com aspecto canibalesco, da fronte carregada, do armamento à vista, da maneira de conduzir seus acompanhantes. Um poder que submete e intimida através da força bruta, como está bem ilustrado na figura dos "tristes três" cavaleiros que são constrangidos e obrigados: "Os três seriam seus prisioneiros, não seus sequazes” (p.13) a acompanhá-lo para fazer a vez de testemunhas do diálogo que o facínora pretende travar com o médico: “ - (...) Estes aí são de nada não. São da Serra. Só vieram comigo, pra testemunho” (p. 13).

Nesse primeiro instante, a tensão surge, na alma do narrador, em virtude da dúvida a respeito da identidade do cavaleiro: o estar-se diante do incógnito desencadeia uma condição de sobrecarga mental e emocional. Aqueles sinais captados pelos olhos indicam a presença de uma força bruta contra a qual o homem letrado, sem habilidade belígera, nada pode fazer, além de sentir o frio da ameaça e perceber a precariedade da sustentação de um confronto físico. Trata-se de um estado de impotência expresso menos pelo simples fato de não ter uma arma de fogo ao alcance, ou por saber que, mesmo se a tivesse, nenhuma diferença faria ante o que sugere a aparência e a forma de portarse do desconhecido, do que pelo sentimento de medo derivado, ironicamente, da mesma raiz que move o jagunço a bater à sua porta: ver-se em estado extremo de "ignorância em momento agudo".

Vivendo um conflito ilusório, na medida em que a iminência do enfrentamento vai se revelar como fruto de um erro de percepção motivado pelo sentimento extremo de medo, o narrador

\footnotetext{
${ }^{2}$ Doravante, todas as citações que se referirem ao conto "Famigerado" de Guimarães Rosa serão indicadas apenas pelo número da página (cf. referência bibliográfica ao final do texto).
} 
intenta levar o confronto para um campo mais favorável. Na esfera do verbal, a palavra medida, previamente pensada, manifesta-se como estratégia para defrontar o inusitado. "Muito de macio, mentalmente, (começa a se) organizar" (p.14) com fim de saber quem é e o que quer seu potencial oponente. Assim, ter a posse do conhecimento e superar a ignorância converte-se também em objetivo narrador.

$\mathrm{Na}$ busca por respostas a respeito da identidade do homem à sua frente, o narrador defrontase com a potencialidade da violência do estranho, confirmada posteriormente também na forma simbólica de um nome e das narrativas a ele relacionadas - Damázio Siqueira, "o feroz de estórias de léguas". Num jogo de revelar e encobrir, o deslindar do nome do cavaleiro traz consigo a incerteza a respeito dos motivos da visita do afamado facínora. A partir desse ponto a nova preocupação aguda faz a tensão articular-se de maneira a descrever um crescendo. Esse novo enigma, proposto pelo próprio revelar da identidade, faz a atenção desviar-se da fisionomia ou dos gestos para o discurso do outro:

Com arranco, calou-se. Como arrependido de ter começado assim, de evidente. Contra que aí estava com o fígado em más margens; pensava, pensava. Cabismeditado. (...)

O que frouxo falava: de outras, diversas pessoas e coisas, da Serra, do São Ão, travados assuntos, insequentes, como dificultação. A conversa era para teias de aranha. (...) Assim no fechar-se com o jogo, sonso, no me iludir, ele enigmava. (p. 15)

$\mathrm{Na}$ esfera do verbal, não só a palavra meditada, mas também, o silêncio tencionado e calculado de quem ouve o outro "para entender-lhe as mínimas entonações, seguir seus propósitos e silêncios" (p.15) torna-se estratégia para a revelação da segunda incógnita. E de fato fica-se sabendo que Damázio Siqueira viera procurar auxílio para também desvendar uma dúvida:

Saiba vosmecê que saí ind'hoje da Serra, que vim, sem parar, essas seis léguas, expresso direto pra mor de lhe preguntar a pregunta, pelo claro... (...)

Vosmecê agora me faça a boa obra de querer me ensinar o que é mesmo que é: fasmisgerado... faz-megerado... falmisgeraldo... familhas-gerado...? (p. 13)

Nesse ponto, verifica-se que a longa viagem de Damázio Siqueira — viagem de seis léguas sobre lombo de cavalo - reveste-se do sentido simbólico de busca. O jagunço vem atrás do homem letrado porque a sua busca pelo conhecimento confunde-se com a procura do próprio elemento que estaria legitimado a revelá-lo. Para Damázio, o revelar do conhecimento só pode ser efetuado por determinados sujeitos sociais que exercem, de alguma forma, uma espécie de posse 
sobre o saber. São agentes reconhecidos e, de alguma maneira, legitimados como detentores desse poder de posse. Como diz Bourdieu,

Isto significa que o poder simbólico não reside nos "sistemas simbólicos" em forma de uma "illocutionary force", mas que se define numa relação determinada e por meio desta - entre os que exercem o poder e os que lhe estão sujeitos, quer dizer, na própria estrutura do campo em que se produz e se reproduz a crença (da legitimidade). (BOURDIEU, 1989, p. 14-5)

Em verdade, o mundo social estrutura-se dentro de um sistema simbolicamente organizado a partir da "lógica da diferença, do desvio diferencial, constituindo assim (a) distinção significante" (BOURDIEU, 1989, p. 144). Dessa forma, o narrador é visto como agente legitimado porque algo o distingue de outros atores sociais. Fica notório no texto o seu letramento, isto é, o domínio de um conjunto de práticas que denotam a capacidade de uso de diferentes tipos de material escrito. Noutras palavras, ele seria proprietário do capital simbólico, estando, assim, qualificado a empreender a interpretação do vocábulo desconhecido pelo jagunço. O próprio Damázio, em sua fala, estabelece as insígnias da distinção, ao evidenciar o desvio diferencial da figura do narrador em relação a tantos outros agentes sociais: “ Lá, e por estes meios de caminho, tem nenhum ninguém ciente, nem têm o legítimo - o livro que aprende as palavras... É gente pra informação torta, por se fingirem de menos ignorâncias... Só se o padre, no São Ão, capaz, mas com padres não me dou: eles logo engambelam...” (p. 15-6)

As palavras de Damázio acabam por configurar-se como expressões simbólicas do poder de que o narrador se vê investido. Elas atuam como emblemas de legitimação, localizando o agente em certo ponto da hierarquia social. Através dessas palavras, fica evidente que iguais ao narrador somente o padre - cuja posição na ordem social de pequenas cidades, com forte vocação rural, é notoriamente proeminente - ou do dicionário - cuja autoridade é quase misticamente inquestionável, cabendo-lhe, inclusive, o qualificativo de "legítimo". É, pois, de fato o reconhecimento aquilo que constitui o letramento, ou qualquer outro atributo, em capital simbólico. Afinal "reconhecer", neste caso, implica que um agente, munido de conceitos genéricos, abstratos, fundamentais resultantes da incorporação do estatuto de um sistema simbólico, entreveja, no outro, o atributo como algo óbvio e natural. Em outras palavras, “o poder simbólico como poder de constituir o dado pela enunciação, de fazer ver e fazer crer, de confirmar ou de transformar a visão do mundo e, deste modo, a ação sobre o mundo, portanto o mundo (...) só se exerce se for reconhecido, quer dizer, ignorado como arbitrário (BOURDIEU, 1989, p. 14).

Reconhecido, assim, o poder simbólico de que está investido o narrador, as ações do jagunço passam a depender exclusivamente da resposta ou de um veredicto daquele que é considerado 
legitimado para tanto. Observe que, de início, o esclarecimento que é dado a respeito do significado da palavra "famigerado" parece ser ineficaz. Mas, na realidade, é uma estratégia discursiva cujo efeito retórico visa, ao mesmo tempo, produzir uma fachada de objetividade e evidenciar os trunfos diferenciais que qualificam e distinguem o narrador como agente que ocupa uma posição destacada na hierarquia social. Assim, "inóxio", "vilta”, “doesto”, por não serem acessíveis à compreensão dos comuns, gente "de em dia-de-semana", tornam manifesta - embora não criem - a distinção de quem exerce a posse do poder sobre o enunciar. Lembre-se ainda que "o que faz o poder das palavras (...) poder de manter a ordem ou de a subverter é a crença na legitimidade das palavras e daquele que as pronuncia, crença cuja produção não é da competência das palavras" (BOURDIEU, 1989, p. 14-5).

De fato, o poder simbólico utiliza-se da enunciação para criar formas de perceber o mundo e de torná-las críveis, validando ou alterando a maneira subjetiva de ver e entender especialmente as relações humanas e os papéis das pessoas e do próprio indivíduo na sociedade. Mas esse poder aparentemente recôndito só se concretiza através do "reconhecimento", ou seja, dentro e por meio de uma vinculação determinada que se estabelece entre os que exercem o poder e os que a ele se submetem, quer dizer, no interior da própria estrutura do campo onde a "crença da legitimidade" origina-se e perpetua-se.

Não é surpreender, portanto, que as palavras de Damázio Siqueira - ao ouvir as explicações do narrador, de que o termo "famigerado" não é "nome de ofensa", e com elas se contentar façam o reconhecimento da legitimidade do homem letrado, adjetivando seus atributos diferenciais com um qualificativo que talvez a ele, Damázio, seja mais caro, pois compreende as características próprias de quem se mostra forte, enérgico, viril: "Não há como que as grandezas machas duma pessoa instruída!” (p. 16-7).

\section{REFERÊNCIAS:}

BLANCHOT, Maurice. O livro por vir. Trad. Maria Regina de Louro. 13. ed., Lisboa: Relógio d’Água, 1984.

BOURDIEU, Pierre. O poder simbólico. Trad. Fernando Tamaz. Rio de Janeiro: Bertrand Brasil, 1989.

BOURDIEU, Pierre. A economia das trocas linguísticas: o que falar o que dizer. São Paulo: EDUSP, 1996.

ROSA, João Guimarães. Famigerado. In: ROSA, João Guimarães. Primeiras estórias. Rio de Janeiro: Nova Fronteira, 1988. 